\title{
KONTRIBUSI PENDAPATAN PEKERJA USAHA BERKAH CONE TERHADAP PENDAPATAN KELUARGA DI KELURAHAN SUMOMPO KECAMATAN TUMINTING KOTA MANADO
}

\section{INCOME CONTRIBUTION OF BERKAH CONE BUSINESS WORKERS TO FAMILY INCOME IN SUMOMPO SUB-DISTRICT OF TUMINTING DISTRICT MANADO CITY}

\author{
Elfira Sari_(1), Gene Henfried Meyer Kapantow ${ }^{(2)}$, Audrey Julia Maria Maweikere_(2)
}

1) Mahasiswa Program Studi Agribisnis, Fakultas Pertanian, Universitas Sam Ratulangi, Manado 2) Dosen Program Studi Agribisnis, Fakultas Pertanian, Universitas Sam Ratulangi, Manado *Penulis untuk korespondensi: elfiraaru@gmail.com

\begin{tabular}{lrr}
\hline Naskah diterima melalui Website Jurnal Ilmiah agrisosioekonomi@unsrat.ac.id & $:$ & Sabtu, 27 Februari 2021 \\
Disetujui diterbitkan & $:$ & Jumat, 28 Mei 2021 \\
\hline
\end{tabular}

\begin{abstract}
This study aimed to determine the contribution of income of the Berkah Cone business workers to their family income. This research was conducted for 3 months, starting from January to March 2020. The data used in this study were primary and secondary data. Primary data were obtained from direct interviews with Berkah Cone business workers and Berkah Cone business owners. Secondary data were obtained from monographs of Sumompo Sub-district and literature related to research. The sampling method used was a census to all workers consisted of 12 people. The results of this study indicated that the income of the Berkah Cone business workers has a $69.75 \%$ contribution to the family income. The value of $69.75 \%$ according to the contribution assessment criteria belongs to the very large category (> 50\%). This means that the income earned by workers in the Blessing Cone business greatly helped their families and themselves in fulfilling theirdaily needs and making a real contribution to the family income.
\end{abstract}

Keywords: income contribution; family income; small ice cream cone industry

ABSTRAK

Penelitian ini bertujuan untuk mengetahui kontribusi pendapatan pekerja usaha Berkah Cone terhadap pendapatan keluarga. Penelitian ini dilaksanakan selama 3 bulan, mulai dari bulan Januari sampai Maret 2020. Data yang digunakan dalam penelitian ini adalah data primer dan data sekunder. Data primer diperoleh dari wawancara langsung dengan pekerja usaha Berkah Cone dan pemilik usaha Berkah Cone. Data sekunder diperoleh dari Monografi Kelurahan Sumompo dan pustaka yang berkaitan dengan penelitian. Metode pengambilan sampel adalah sensus dengan jumlah responden 12 orang. Hasil dari penelitian ini menunjukkan kontribusi pendapatan pekerja usaha Berkah Cone sebesar $69,75 \%$ terhadap pendapatan keluarga. Nilai 69,75\% menurut kriteria penilaian kontribusi tergolong dalam kategori sangat besar ( $>50 \%)$. Ini berarti pendapatan yang diperoleh pekerja sebagai buruh pada usaha Berkah Cone sangat membantu keluarga maupun diri sendiri dalam memenuhi kebutuhan setiap hari dan memberikan kontribusi yang nyata terhadap pendapatan keluarga.

Kata kunci : Konribusi pendapatan; pendapatan keluarga; industri kecil cone es krim 


\section{PENDAHULUAN}

\section{Latar Belakang}

Usaha Mikro, Kecil dan Menengah (UMKM) mempunyai peran penting dalam pembangunan ekonomi nasional. Selain berperan dalam pertumbuhan ekonomi dan penyerapan tenaga kerja, UMKM juga berperan dalam mendistribusikan hasil-hasil pembangunan. Menurut Anggraeni (2013), Pengembangan UMKM menjadi sangat strategis dalam menggerakan perekonomian nasional, mengingat kegiatan usahanya mencakup hampir semua lapangan usaha sehingga kontribusi UMKM menjadi sangat besar bagi peningkatan pendapatan bagi kelompok masyarakat berpendapatan rendah.

Menurut Sinadia (2017), Kontribusi adalah keikutsertaan, keterlibatan, melibatkan diri maupun sumbangan. Dalam hal ini kontribusi tidak hanya berupa tindakan saja melainkan berupa materi, dengan berkontribusi berarti individu berupaya untuk meningkatkan kehidupannya. Salah satu bentuk kontribusi para pelaku UMKM untuk meningkatkan kehidupan mereka yaitu dengan mengembangkan usaha mereka dan dapat menarik banyak tenaga kerja, sehingga bukan hanya pemilik industri/usaha yang dapat berkontribusi untuk meningkatkan kehidupan mereka, namun para pekerja di industri/usaha itu juga dapat berkontribusi untuk pendapatan keluarga mereka.

Untuk mencukupi kebutuhan keluarga serta meningkatkan taraf hidup, banyak masyarakat yang mulai menjadi para pelaku usaha dengan membangun usaha-usaha berskala kecil, menengah hingga berskala besar. Dalam hal ini tentu saja sangat membantu mengurangi jumlah pengangguran di Indonesia, berkat banyaknya pertumbuhan UMKM yang banyak menyerap tenaga-tenaga kerja. Menurut Noor (2019), Pekerja suatu industri/usaha kecil menggantungkan sebagian besar sumber pendapatan mereka dari usahausaha tersebut, sehingga dari situ diharapkan pendapatan dari pekerjaan mereka berpengaruh positif terhadap pertumbuhan ekonomi keluarga.
Industri pangan merupakan salah satu industri yang memiliki potensi untuk dikembangkan, salah satunya ialah industri pembuatan Cone es krim yang memiliki bahan dasar dari hasil pertanian. Secara kuantitatif belum ada data yang menggambarkan jumlah konsumsi Cone es krim. Meskipun demikian dapat diperkirakan bahwa jumlah konsumsi Cone es krim relatif tinggi. Karena Cone es krim merupakan ciri khas pelengkap es krim, selain es krim stick es krim Cone adalah es krim yang sangat digemari anak-anak dan remaja. Dari segi permintaan, dengan bertambahnya jumlah penduduk dan kualitas hidup maka permintaan terhadap produk akan semakin bertambah.

Cone es krim terbuat dari bahan dasar tepung terigu ataupun tepung sagu. Salah satu faktor yang sangat mempengaruhi kualitas produk bakery seperti wafer, yaitu penggunaan tepung terigu pada bahan pembuatannya. Matz dalam Herina (2018), menyebutkan bahwa protein yang unik pada terigu yaitu gluten, dapat menghasilkan struktur produk bakery yang dapat mengembang tinggi dan mempengaruhi tekstur produk yang dihasilkannya.

Industri pembuatan Cone es krim merupakan industri kecil. Usaha Cone es krim mempunyai peluang besar untuk dikembangkan baik untuk konsumen dalam negeri maupun untuk di ekspor.

\section{Rumusan Masalah}

Adapun rumusan masalah dari penelitian ini adalah seberapa besar kontribusi pendapatan pekerja terhadap pendapatan keluarga di usaha Berkah Cone, Kelurahan Sumompo, Kecamatan Tuminting, Kota Manado?

\section{Tujuan Penelitian}

Penelitian ini bertujuan untuk mengetahui kontribusi pendapatan pekerja usaha Berkah Cone terhadap pendapatan keluarga mereka.

\section{Manfaat Penelitian}

Adapun manfaat dari penelitian ini nantinya yaitu: 
1. Bagi peneliti, penelitian ini sebagai salah satu karya ilmiah untuk mengembagkan pengetahuan dan wawasan mengenai industri kecil pembuat Cone.

2. Bagi pihak usaha Berkah Cone, dapat menjadi bahan masukan maupun wawasan yang kiranya bisa bermanfaat dalam pengembangan usaha.

3. Bagi pembaca dan pihak lain, diharapkan dapat menambah wawasan dan pengetahuan seputar kontribusi pendapatan usaha kecil terhadap pertumbuhan ekonomi serta dapat memberikan informasi sebagai acuan untuk penelitian selanjutnya.

\section{METODE PENELITIAN}

\section{Waktu dan Tempat Penelitian}

Penelitian ini dilaksanakan pada usaha Berkah Cone di Kelurahan Sumompo, Kecamatan Tuminitng, Kota Manado, Provinsi Sulawesi Utara. Penelitian ini berlangsung selama 3 bulan yang dimulai dari bulan Januari 2020 hingga Maret 2020.

\section{Metode Pengumpulan Data}

Jenis dan sumber data yang digunakan dalam penelitian ini adalah data primer dan data sekunder. Data primer diperoleh melalui wawancara langsung dengan pekerja serta pemilik usaha kerupuk es krim (Cone). Instrumen penelitian yang digunakan untuk memudahkan proses pengambilan data yaitu dengan menggunakan Kuesioner atau daftar pertanyaan yang telah disusun sesuai kebutuhan peneliti. Data sekunder yang digunakan diperoleh dari data Monografi Kelurahan Sumompo. Selain itu, juga diperoleh dengan membaca literatur yang terkait dengan topik penelitian, yaitu berasal dari perpustakaan, internet, buku dan hasil penelitian terdahulu yang relevan.

\section{Metode Pengambilan Sampel}

Metode pengambilan sampel dilakukan dengan sensus dan mengambil seluruh populasi pekerja usaha Berkah Cone di Kelurahan Sumompo. Jumlah sampel sebagai responden yaitu 12 pekerja.

\section{Konsep Pengukuran Variabel}

Variabel yang diukur dalam penelitian ini adalah:

a. Karakteristik responden, yang meliputi:

- Umur pekerja (tahun),

- Tingkat pendidikan (SD, SMP, SMA/SMK),

- Status dalam rumah tangga (Kepala keluarga, Ayah, Ibu, Isteri dan anak)

- Jumlah anggota keluarga (orang).

- Alasan bekerja, yaitu dorongan yang timbul untuk bekerja di usaha Berkah Cone.

- Lama bekerja responden

- Pekerjaan anggota keluarga responden

b. Kontribusi pendapatan responden, yang meliputi:

- Rata-rata pendapatan pekerja usaha Berkah Cone (Rp/bulan)

- Rata-rata pendapatan anggota keluarga yang tidak bekerja di usaha Berkah Cone yang termasuk istri/ suami dan tanggungan keluarga lainnya (Rp/bulan).

- Kontribusi pendapatan pekerja Berkah Cone terhadap pendapatan keluarga dalam persentase $(\%)$.

\section{Metode Analisis Data}

Penelitian ini menggunakan pendekatan kuantitatif sesuai dengan tujuan penelitian untuk melihat kontribusi pekerja usaha Berkah Cone terhadap pendapatan keluarga.

Analisis data yang digunakan dalam penelitian ini adalah Analisis Data Kontribusi, yaitu analisis yang digunakan untuk mengetahui seberapa besar kontribusi pekerja usaha Berkah Cone terhadap pendapatan keluarga perbulan dalam persentase.

Untuk mengetahui besarnya kontribusi pekerja Berkah Cone terhadap pendapatan keluarga digunakan rumus:

Kontribusi $=\frac{\mathrm{X}_{1}}{\mathrm{X}_{2}} \times 100 \% \ldots . . .($ Zulfikri dkk,2014) Dimana:

$\mathrm{X}_{1} \quad=$ Pendapatan pekerja

$\mathrm{X}_{2}=$ Total pendapatan keluarga 


$$
\text { Kontribusi pekerja }=\frac{\text { Pendapatan pekerja }}{\text { Total pendapatan keluarga }} \times 100 \%
$$

Adapun besarnya pendapatan keluarga diperoleh dari Rumus:

Pendapatan keluarga = Pendapatan suami/pekerja + pendapatan isteri/ibu + pendapatan anggota keluarga lain

Mengikuti kriteria penilaian Kontribusi dari Zulfikri, dkk (2014), maka dirasa perlu untuk membuat perubahan pada kategori penilaian kontribusi menjadi:

\begin{tabular}{cc} 
Tabel 1. Kriteria Kontribusi Pendapatan \\
\hline $\begin{array}{c}\text { Persentase Tingkat } \\
\text { Kontribusi }\end{array}$ & Kriteria Kontribusi \\
\hline $0,00-10,00 \%$ & Sangat kecil \\
$10,01-20,00 \%$ & Kecil \\
$20,01-30,00 \%$ & Sedang \\
$30,01-40,00 \%$ & Cukup \\
$40,01-50,00 \%$ & Besar \\
$>50 \%$ & Sangat besar \\
\hline
\end{tabular}

\section{HASIL DAN PEMBAHASAN}

\section{Profil Usaha Berkah Cone}

Usaha Berkah Cone merupakan usaha yang bergerak di industri pangan sudah berdiri sejak tahun 2005. Usaha ini didirikan oleh Bapak Ahmad Saiin dan Ibu Sutani. Lokasi dari pabrik Cone ini yaitu terletak di Kelurahan Sumompo Kecamatan Tuminting Kota Manado. Usaha ini memiliki jumlah tenaga kerja sebanyak 12 orang dengan upah perminggu atau dengan sistem borong. Usaha Berkah Cone berproduksi 6 hari dalam seminggu yaitu pada hari senin sampai dengan hari sabtu dimulai dari jam 05.00-15.00 WITA, namun karna menggunakan sistem borong atau gaji sesuai dengan hasil pekerjaan maka pekerja boleh lembur atau pulang lebih awal. Usaha Berkah Cone dalam sehari menghabiskan rata-rata 40 $\mathrm{Kg}$ tepung tapioka, $20 \mathrm{Kg}$ tepung terigu, $2 \mathrm{Kg}$ minyak dan 30 liter air. Sedangkan jumlah Cone yang dapat diproduksi dalam sehari menurut wawancara dengan responden bisa mencapai 810 pack, dalam 1 pack ada yang berisi 20 pcs Cone dengan ukuran besar dan ada yang berisi 40 pcs
Cone dengan ukuran kecil. Daerah pemasaran Usaha Berkah Cone yaitu dalam Provinsi yang meliputi Manado, Bitung, Minahasa Tenggara, Minahasa Induk, Kotamobagu dan juga keluar Provinsi yang meliputi Gorontalo dan juga Luwuk.

\section{Deskripsi Umum Daerah Penelitian Kondisi Geografis Daerah Penelitian}

Kelurahan Sumompo merupakan sebuah kelurahan yang terletak di Kecamatan Tuminting, Kota Manado dengan luas wilayah 101,6 Ha. Secara geografis, Kelurahan Sumompo dibatasi oleh:
a. Sebelah Utara : Kelurahan Bailang dan Kelurahan Buha
b. Sebelah Selatan : Kelurahan Tuminting
c. Sebelah Barat : Kelurahan Singkil Satu
d. Sebelah Timur : Kelurahan Mahawu

Kelurahan Sumompo terbagi menjadi 5 wilayah lingkungan. Perangkat desa di Kelurahan Sumompo terdiri dari seorang Kepala Desa (Kades), 1 orang Kepala Seksi, dan 5 orang Kepala Lingkungan (Dusun).

\section{Kondisi Demografis di Kelurahan Sumompo}

Secara demografis jumlah kepala keluarga di Kelurahan Sumompo adalah 2.063 KK yang terdiri dari 7.168 jiwa. Penduduk Kelurahan Sumompo berjumlah 7.168 jiwa, yang terdiri dari laki-laki 3.602 jiwa dan perempuan 3.566 jiwa.

\section{Karakteristik Responden}

Karakteristik responden yang dimaksud disini ialah umur responden, tingkat pendidikan, status dalam rumah tangga, jumlah anggota keluarga, alasan bekerja, lama bekerja dan pekerjaan anggota keluarga dari pekerja usaha Berkah Cone.

Tabel 2. Karakteristik Responden

\begin{tabular}{|c|c|c|c|c|}
\hline No. & Uraia & & Satuan & Range \\
\hline 1. & Umur & & Tahun & 16-36 \\
\hline 2. & $\begin{array}{l}\text { Jumlah } \\
\text { Keluarga }\end{array}$ & Anggota & Orang & $1-8$ \\
\hline 3. & Pendidikan & & Tahun & $9-12$ \\
\hline
\end{tabular}




\section{Umur Pekerja}

Umur merupakan salah satu faktor yang menjadi pertimbangan dalam tangkat partisipasi angkatan kerja sekaligus menjadi faktor pendukung seseorang untuk mengambil keputusan memasuki dunia kerja. Pekerja dengan umur produktif biasanya produkivitas dan kemampuan bekerjanya akan bertambah karena umur dan kondisi fisiknya masih prima.

Tabel 3. Distribusi Responden Menurut Kelompok Umur

\begin{tabular}{ccc}
\hline Umur (Tahun) & \multicolumn{2}{c}{ Total } \\
\cline { 2 - 3 } & $\mathbf{N}$ & $\mathbf{\%}$ \\
\hline$<30$ & 8 & 66,67 \\
$\geq 30$ & 4 & 33,33 \\
\hline Jumlah & $\mathbf{1 2}$ & $\mathbf{1 0 0 , 0 0}$ \\
\hline Sumber: Data Primer, diolah pada tahun 2020
\end{tabular}

Tabel 2 menunjukkan kisaran umur responden adalah 16 sampai dengan 36 tahun, maka dapat dikatakan bahwa seluruh pekerja yang bekerja pada usaha Berkah Cone berada pada usia produktif atau sesuai dengan penggolongan umur produktif kerja menurut Badan Pusat Statistik (2019) yaitu berada pada usia 15-64 tahun.

Umur pekerja Berkah Cone tertinggi yaitu 36 tahun dan terendah 16 tahun. Tabel 3 menunjukkan bahwa responden dengan umur dibawah 30 tahun berjumlah 8 orang $(66,67 \%)$. Sedangkan pekerja yang berusia diatas atau sama dengan 30 tahun berjumlah 4 orang $(33,33 \%)$. Pekerja dengan usia yang tergolong muda sangat cocok dengan usaha Berkah Cone karena kondisi fisik yang masih prima.

\section{Tingkat Pendidikan}

Kualitas sumber daya manusia diketahui dari beberapa faktor, salah satunya ialah tingkat pendidikan. Pendidikan menentukan tingkat produktivitas seseorang, semakin lama pendidikan seseorang semakin baik kualiatas kerjanya.

\begin{tabular}{ccc}
\multicolumn{2}{c}{ Tabel 4. Distribusi Responden Menurut Tingkat Pendidikan } \\
\hline \multirow{2}{*}{ Tingkat Pendidikan } & \multicolumn{2}{c}{ Total } \\
\cline { 2 - 3 } & $\mathbf{N}$ & \% \\
\cline { 2 - 3 } SMP & 5 & 41,67 \\
SMA & 7 & 58,33 \\
\hline Jumlah & $\mathbf{1 2}$ & $\mathbf{1 0 0 , 0 0}$ \\
\hline Sumber: Data Primer, diolah pada tahun 2020
\end{tabular}

Pekerja pada usaha Berkah Cone tidak dituntut berpendidikan formal tinggi. Pendidikan pekerja Berkah Cone terendah yaitu tamat SMP dan tertinggi tamat SMA. Tabel 4 menunjukkan bahwa responden dengan tingkat pendidikan 9 tahun (SMP) berjumlah 5 orang (41,67\%). Sedangkan responden yang berpendidikan 12 tahun (SMA) berjumlah 7 orang $(58,33 \%)$. Hal ini menunjukkan pekerja usaha Berkah Cone sebagian besar sudah memiliki tingkat pendidikan yang baik.

\section{Status Dalam Keluarga}

Keluarga adalah lingkungan dimana beberapa orang yang masih memiliki hubungan darah. Menurut Soerjono (2004), Keluarga didefinisikan sebagai sekumpulan orang yang tinggal dalam satu rumah yang masih mempunyai hubungan kekerabatan/hubungan darah karena perkawinan, kelahiran, adopsi dan lain sebagainya. Dalam memasuki sebuah keluarga, seseorang diwarisi suatu rangkaian status. Seseorang menerima beberapa status dalam keluarga berdasarkan umur, jenis kelamin, urutan kelahiran dan lainnya (Supriatna, 2006).

Tabel 5. Distribusi Responden Menurut Status Dalam Keluarga

\begin{tabular}{|c|c|c|}
\hline No. & Status Dalam Keluarga & Jumlah \\
\hline 1. & $\begin{array}{l}\text { Menikah } \\
\text { keluarga/Suami) }\end{array}$ & 3 orang \\
\hline 2. & Menikah (Isteri) & 4 orang \\
\hline 3. & Anak & 1 orang \\
\hline 4. & Adik Kandung & 2 orang \\
\hline 5. & Belum Menikah & 2 orang \\
\hline & Jumlah & 12 orang \\
\hline
\end{tabular}

Responden yang diteliti ada yang sudah berkeluarga dan berstatus sebagai suami atau kepala keluarga, berjumlah 3 orang pekerja. Ada 4 orang pekerja yang berstatus sebagai istri atau ibu rumah tangga, 1 orang pekerja yang belum berkeluarga dan berstatus sebagai anak yang tinggal satu atap dengan Ayah kandung dan Ibu tiri, ada pula 2 orang pekerja yang belum berkeluarga dan berstatus sebagai adik yang tinggal satu atap dengan Kakak kandung. Terdapat 2 orang pekerja yang belum berkeluarga atau belum menikah. 


\section{Jumlah Anggota Keluarga}

Jumlah anggota keluarga merupakan banyaknya orang yang tinggal dalam satu atap dan makan dalam satu dapur yang meliputi suami, istri, anak dan anggota keluarga lainnya yang menjadi beban tanggungan dalam keluarga. Semakin banyak jumlah anggota keluarga maka akan membuat beban tanggungan kepala rumah tangga semakin berat, apalagi jika anggota rumah tangga tersebut belum berumur produktif. Tabel 2 memperlihatkan bahwa jumlah anggota keluarga responden berkisar 18 orang.

\begin{tabular}{lccc} 
Tabel & $\begin{array}{l}\text { 6. Distribusi } \\
\text { Tanggungan Keluarga }\end{array}$ & $\begin{array}{c}\text { Responden } \\
\text { Numlah }\end{array}$ & $\begin{array}{l}\text { Persentase } \\
(\mathbf{\%})\end{array}$ \\
\hline No. & $\begin{array}{l}\text { Jumlah } \\
\text { anggota } \\
\text { keluarga }\end{array}$ & $\begin{array}{l}\text { Jumut } \\
\text { responden }\end{array}$ & Jumlah \\
\hline 1. & 1 & 2 & 16,67 \\
2. & 3 & 4 & 33,33 \\
3. & 4 & 3 & 25,00 \\
4. & $\geq 5$ & 3 & 25,00 \\
\hline & Jumlah & $\mathbf{1 2}$ & $\mathbf{1 0 0 , 0 0}$ \\
\hline
\end{tabular}

Sumber: Data Primer, diolah pada tahun 2020

Tabel 6 menunjukkan bahwa dari 12 responden, sampel terbanyak adalah sampel yang memiliki 3 tanggungan keluarga yaitu sebanyak 4 orang $(33,33 \%)$, dan yang paling sedikit memiliki 1 tanggungan keluarga yaitu sebanyak 2 orang $(16,67 \%)$ karena tinggal dimess pabrik atau tidak tinggal dengan keluarga besar.

\section{Alasan Bekerja}

Kebutuhan hidup yang semakin hari semakin bertambah sehingga membuat tuntutan ekonomi menjadi fokus utama bagi sebagian besar responden. Dari hasil wawancara diketahui bahwa beberapa responden memberikan kontribusi pendapatan kepada keluarga mereka yang tinggal di Gorontalo dari hasil bekerja di usaha Berkah Cone.

Tabel 7 menunjukkan bahwa responden yang memiliki alasan bekerja di usaha Berkah Cone karena ingin menambah pendapatan keluarga sebanyak 8 orang $(66,67 \%)$ dan responden dengan alasan bekerja tidak punya pilihan pekerjaan lain sebanyak 4 orang $(33,33 \%)$.
Tabel 7. Distribusi Responden Menurut Alasan Bekerja

\begin{tabular}{llcc}
\hline \multirow{2}{*}{ No. } & \multicolumn{2}{c}{ Alasan } & \multicolumn{2}{c}{ Total } \\
\cline { 3 - 4 } 1. & $\begin{array}{l}\text { Menambah } \begin{array}{c}\text { N pendapatan } \\
\text { keluarga } \\
\text { Tidak punya } \\
\text { pekerjaan lain }\end{array} \\
\text { 2. }\end{array}$ & 8 & 66,67 \\
\hline \multicolumn{1}{c}{ Jumlah } & 4 & 33,33 \\
\hline Sumber: Data Primer, diolah pada tahun 2020 & $\mathbf{1 2}$ \\
\hline
\end{tabular}

\section{Lama Bekerja Responden}

Berdasarkan wawancara dengan responden diketahui lama waktu para responden bekerja diusaha Berkah Cone dapat dilihat pada Tabel 7.

Tabel 7. Distribusi Lama Bekerja Responden

\begin{tabular}{lccc} 
& & \multicolumn{2}{c}{ Total } \\
\cline { 3 - 4 } No. & Lama Bekerja & N & \% \\
\hline 1. & $<1$ tahun & 5 & 41,67 \\
2. & 1 tahun $-\leq 3$ tahun & 3 & 25,00 \\
3. & $>3$ tahun & 4 & 33,33 \\
\hline \multicolumn{2}{r}{ Sumber: Data Primer, diolah pada tahun 2020}
\end{tabular}

Tabel 7 menunjukkan bahwa responden dengan lama bekerja $<1$ tahun berjumlah 5 orang dengan persentase sebesar $41,67 \%, 3$ orang responden dengan lama bekerja 1 tahun $\leq 3$ tahun dengan persentase $25 \%$ dan responden dengan lama bekerja $>3$ tahun berjumlah 4 orang dengan persentase $33,33 \%$. Hal ini menunjukkan hampir setengah dari jumlah pekerja adalah pekerja baru, berdasarkan wawancara dengan pemilik pabrik sebagian dari pekerja lama adalah saudara atau masih memiliki hubungan keluarga dengan pemilik. Sedangkan pekerja baru kebanyakan adalah dari kenalan atau tetangga yang membutuhkan pekerjaan untuk menambah pendapatan keluarga mereka.

\section{Pekerjaan Anggota Keluarga Responden}

Berdasarkan wawancara dengan responden hanya terdapat 6 orang anggota keluarga yang sudah dalam usia bekerja. Pekerjaan anggota keluarga responden dapat dilihat di Tabel 8.

Tabel 8. Distribusi Anggota Keluarga Responden menurut

\begin{tabular}{llcc}
\multicolumn{4}{c}{ Pekerjaan } \\
\hline No. & \multicolumn{1}{c}{ Pekerjaan } & Jumlah (jiwa) & Persentase \\
\hline 1. & IRT & 1 & 16,67 \\
2. & Pekerja meubel & 1 & 16,67 \\
3. & Tukang bangunan & 1 & 16,67 \\
4. & Ojek & 1 & 16,67 \\
5. & Karyawan swasta & 2 & 33,32 \\
\hline \multicolumn{4}{l}{ Sumber: Data Primer, diolah tahun 2020 }
\end{tabular}


Tabel 8 menunjukkan bahwa sebagian besar anggota keluarga responden yang sudah dalam umur produktif bekerja, ikut serta dalam memberikan sumbangan penghasilan terhadap pendapatan keluarga dengan bekerja sebagai pekerja meubel berjumlah 1 orang $(16,67 \%)$, bekerja sebagai tukang bangunan 1 orang $(16,67 \%)$, sebagai tukang ojek 1 orang $(16,67 \%)$, dan 2 orang bekerja sebagai karyawan swasta $(33,32 \%)$ sedangkan 1 orang $(16,67 \%)$ anggota keluarga bekerja sebagai ibu rumah tangga (IRT).

\section{Hasil Penelitian \\ Rata-rata Pendapatan Responden}

Pendapatan pekerja adalah pendapatan yang diterima langsung setelah bekerja. Dari hasil wawancara dengan responden yang bekerja di Berkah Cone bahwa pendapatan yang mereka dapat dari bekerja adalah dengan sistem borong atau sesuai dengan pekerjaaan mereka, semakin banyak mereka mencetak Cone maka semakin banyak pendapatan yang mereka dapat. Berikut pendapatan pekerja Berkah Cone dapat dilihat pada Tabel 9.

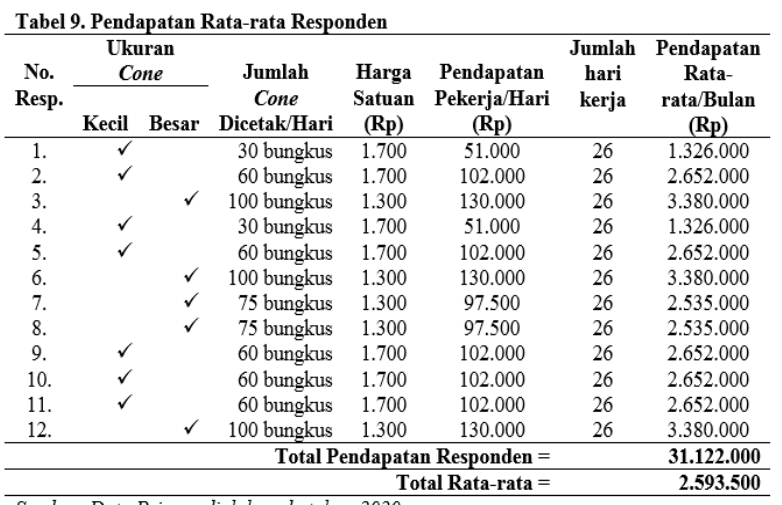

Tabel 9 menunjukkan bahwa total pendapatan dari 12 orang pekerja setiap bulan sebesar Rp. 31.122.000,- per bulan dengan ratarata yaitu Rp. 2.593.500,-. Pendapatan paling banyak yaitu Rp. 3.380.000,-/bulan, pendapatan ini relatif standar atau sesuai penetapan UMP Provinsi Sulawesi Utara yaitu Rp. 3.310.723,-. Sedangkan pendapatan paling sedikit yaitu Rp. 1.326.000,-, pendapatan ini relatif kecil atau kurang dari UMP Sulawesi Utara namun pekerja tetap memilih bekerja sebagai buruh karena berbagai alasan seperti ingin menambah pendapatan keluarga dan tidak memiliki pilihan pekerjaan lain. Sehingga mereka memilih lebih baik bekerja dengan upah rendah daripada tidak bekerja sama sekali agar dapat berkontribusi bagi pendapatan keluarga.

\section{Rata-rata Pendapatan Anggota Keluarga Responden}

Pendapatan keluarga adalah pendapatan bersih yang diperoleh dari suami/kepala rumah tangga, isteri dan anggota keluarga lain yang bekerja selama satu bulan dan tinggal dalam satu atap atau makan dalam satu dapur. Dalam penelitian ini, terdapatan beberapa anggota keluarga yang tinggal satu atap memiliki pekerjaan sama yaitu bekerja di usaha Berkah Cone, pada Tabel 15 terdiri dari pendapatan ratarata pekerja Berkah Cone, serta rata-rata pendapatan non-responden, yaitu anggota keluarga yang makan dalam satu dapur dan sudah memiliki penghasilan.

Total terdapat 12 responden pekerja Berkah Cone yang diperhitungkan dalam kontribusi pendapatan anggota keluarga. Terdapat 3 keluarga yang masing-masing 2 dari angggota keluarganya menjadi responden atau bekerja di usaha Berkah Cone. Dapat dilihat pada Tabel 10, responden dengan nomor responden $7-12$ merupakan responden dengan 2 anggota keluarga yang bekerja di usaha Berkah Cone. Sedangkan 2 responden lainnya menanggung beban diri sendiri karena tidak makan satu dapur dengan anggota keluarga.

\begin{tabular}{cccccc}
\multicolumn{6}{c}{ Tabel 10. Pendapatan Rata-rata Anggota Keluarga Responden Pekerja Berkah Cone } \\
dalam Rp/bulan
\end{tabular}


Tabel 10 menjelaskan bahwa pendapatan dari masing-masing anggota keluarga (termasuk responden) dihitung dalam Rp/bulan. Pendapatan tertinggi didapat dari pekerja Berkah Cone dengan rata-rata pendapatan Rp. 2.593.500,- per bulan. Pendapatan dari anggota keluarga lain yaitu suami, kakak kandung dan keponakan dari responden, memiliki rata-rata lebih rendah.

Dari hasil wawancara, diketahui bahwa rata-rata tempat tinggal para pekerja dekat dengan pabrik dan terdapat 2 responden yang tinggal di mess pabrik, sehingga meskipun pendapatan yang diperoleh masih rendah, namun pengeluaran yang dimiliki tidak terlalu besar.

\section{Kontribusi Pendapatan Pekerja Usaha Berkah Cone Terhadap Pendapatan Keluarga}

Kontribusi yang dimaksud dalam penelitian ini adalah sumbangan dari seluruh populasi pekerja usaha Berkah Cone sebanyak 12 responden. Menurut hasil wawancara, para pekerja usaha Berkah Cone memperoleh pendapatan seluruhnya hanya dari bekerja di pabrik Cone dan tidak mengusahakan pekerjaan lain.

Untuk mengetahui besar nilai kontribusi pendapatan pekerja usaha Berkah Cone terhadap pendapatan keluarga digunakan perhitungan sebagai berikut:

$$
\text { Kontribusi }=\frac{X_{1}}{X_{2}} \times 100 \ldots \ldots . .(\text { Zulfikri, } 2014)
$$

Dimana:

$\mathrm{X}_{1}=$ Total pendapatan responden selama satu bulan

$\mathrm{X}_{2}=$ Total pendapatan anggota keluarga (termasuk responden) selama satu bulan

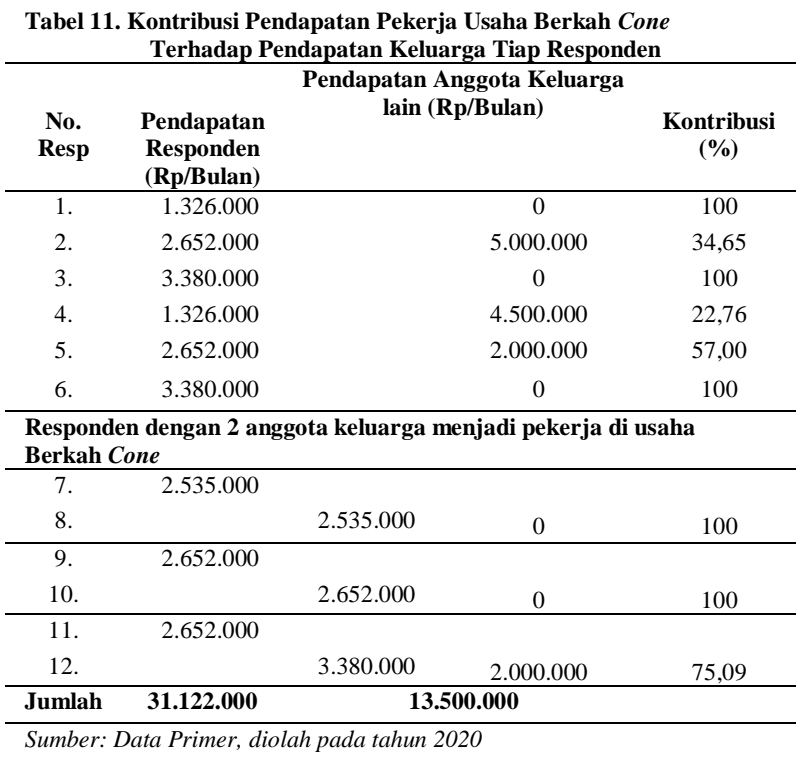

Kontribusi pendapatan pekerja usaha Berkah Cone terhadap pendapatan keluarga terendah yaitu $22,76 \%$ dan tertinggi $100 \%$. Tabel 11 menunjukkan bahwa kontribusi responden dengan kategori sedang berjumlah 1 orang $(22,76 \%)$ dan 1 orang dengan kategori cukup (34,65\%). Sedangkan kontribusi pendapatan pekerja usaha Berkah Cone terhadap keluarga dengan kategori sangat besar $(>50 \%)$ berjumlah 10 orang.

Berdasarkan wawancara yang dilakukan dengan responden diketahui bahwa 7 orang responden memiliki kontribusi sebesar $100 \%$ terhadap pendapatan keluarga dari masing-masing responden tersebut, 4 dari 7 responden tersebut adalah suami istri yang keduanya bekerja di usaha Berkah Cone dan tidak memiliki anggota keluarga lain yang bekerja. Kemudian 2 responden lain yang memiliki kontribusi $100 \%$ masih belum berkeluarga sehingga pendapatan keluarga mereka hanya dari bekerja di usaha Berkah Cone, sedangkan 1 responden didalam keluarga hanya responden terebut yang mencari nafkah. Sedangkan responden dengan kontribusi $<50 \%$ dikarenakan dalam keluarga tersebut ada anggota keluarga yang tinggal dalam satu atap dan makan dalam satu dapur ikut membantu bekerja untuk menambah pendapatan keluarga mereka sehingga pendapatan keluarga tidak hanya berasal dari pekerja di usaha Berkah Cone.

Rata-rata kontribusi $=\frac{2.593 .500}{3.718 .500} \times 100 \%=69,75 \%$

Tabel 12. Kontribusi Pendapatan Pekerja Usaha Berkah Cone Terhadap Pendapatan Keluarga

\begin{tabular}{lccc}
\hline $\begin{array}{c}\text { Anggota } \\
\text { Rumah } \\
\text { Tangga }\end{array}$ & $\begin{array}{c}\text { Total } \\
\text { Pendapatan } \\
(\mathbf{R p} / \text { Bulan) }\end{array}$ & Rata-rata & $\begin{array}{c}\text { Kontribusi } \\
(\mathbf{\%})\end{array}$ \\
\hline Responden & 31.122 .000 & 2.593 .500 & 69,75 \\
Anggota & 13.500 .000 & 1.125 .000 & 30,25 \\
keluarga lain & & & \\
\hline Jumlah & $\mathbf{4 4 . 6 2 2 . 0 0 0}$ & $\mathbf{3 . 7 1 8 . 5 0 0}$ & $\mathbf{1 0 0}$ \\
\hline \multicolumn{4}{l}{ Sumber: Data Primer, diolah pada tahun 2020 }
\end{tabular}

Tabel 12 menunjukkan bahwa total pendapatan responden dan pendapatan keluarga maka rata-rata kontribusi pendapatan pekerja usaha Berkah Cone seluruhnya terhadap pendapatan 
keluarga adalah $69,75 \%$. Berdasarkan kriteria penilaian di Tabel 1, maka kontribusi pendapatan pekerja usaha Berkah Cone terhadap pendapatan keluarga dikategorikan sangat besar karena nilainya $>50 \%$.

Sedangkan, dapat dilihat pula kontribusi anggota keluarga lain responden dari total pendapatan Rp. 13,500,000,- dengan rata-rata $\mathrm{Rp}$. 1,125,000,- diperoleh nilai kontribusi sebesar 30,25\% yang artinya lebih rendah dari kontribusi pekerja Berkah Cone serta dikategorikan cukup karena nilainya berada di range $30,01-40,00 \%$. Nilai kontribusi yang besar dari pekerja Berkah Cone dipengaruhi oleh status sebagian pekerja yang masih belum menikah dan sebagian pasangan suami isteri yang bekerja sebagai pekerja di Berkah Cone, sehingga total pendapatan keluarga hanya berasal dari responden.

Dari hasil wawancara diketahui bahwa sebagian responden baik yang masih belum menikah ataupun yang sudah menikah mengirim uang ke keluarga mereka yang ada di Gorontalo dan di Tompaso secara rutin. Pekerja mengirim uang untuk berbagai keperluan terhadap keluarga mereka karena alasan ingin membantu orang tua atau keluarga mereka. Ada yang untuk memenuhi kehidupan sehari-hari dan ada juga yang sedang menabung untuk membangun rumah di Manado sehingga pendapatan dari bekerja di usaha Berkah Cone sangat membantu dalam merealisasikan hal tersebut.

\section{KESIMPULAN DAN SARAN}

\section{Kesimpulan}

Hasil yang ditemukan dilapangan menunjukkan kontribusi pendapatan pekerja usaha Berkah Cone adalah sebesar 69,75\% terhadap pendapatan keluarga. Nilai $69,75 \%$ menurut kriteria penilaian kontribusi tergolong dalam kategori sangat besar $(>50 \%)$ yang artinya dengan pendapatan yang diperoleh pekerja sebagai buruh pada usaha Berkah Cone sangat membantu keluarga maupun diri sendiri dalam memenuhi dan mencukupi kebutuhan setiap hari dan memberikan kontribusi yang nyata terhadap pendapatan keluarga, sehingga bila tanpa kontribusi dari repsonden, maka kebutuhan dalam keluarga belum dapat tercukupi.

\section{Saran}

Walaupun upah yang diterima dari usaha Berkah Cone masih di bawah UMP, hasil penelitian menunjukkan keluarga pekerja sangat menggantungkan penghasilan mereka dari usaha tersebut. Oleh karena itu untuk meningkatkan kesejahteraan keluarga sebaiknya para pekerja mulai memanfaatkan waktu luang yang ada untuk mendapatkan sumber pendapatan lain.

\section{DAFTAR PUSTAKA}

Anggraeni, D. F. 2013. Pengembangan Usaha Mikro, Kecil, Dan Menengah (UMKM) Melalui Fasilitas Pihak Eksternal Dan Potensi Internal (Studi Kasus pada Kelompok Usaha "Emping Jagung" di Kelurahan Pandanwangi Kecamatan Blimbing, Kota Malang). Jurnal Administrasi Publik (JAP) Volume 1, Nomor 6. Jurusan Administrasi Publik Fakultas Ilmu Administrasi Universitas Brawijaya. Malang.

Herina, M. 2018. Pengaruh Substitusi Tepung Kulit Pisang Kepok (Musa paradisiaca F) Pada Tepung Terhadap Karakteristik Cone Wafer Es Krim. Skripsi, Fakultas Teknik Universitas Pasundan. Bandung.

Noor, S. M. B. 2019. Kontribusi Pendapatan Pekerja Usaha Tahu Nipon Terhadap Pendapatan Keluarga Di Desa Tateli Kecamatan Mandolang Kabupaten Minahasa. Skripsi, Jurusan Sosial Ekonomi Fakultas Pertanian Universitas Sam Ratulangi. Manado. 
Sinadia, B. C. J. 2017. Kontribusi Buruh Perempuan Terhadap Pendapatan Keluarga (Studi Kasus Tempat Pelelangan Ikan Di Tumumpa Kota Manado). Jurnal Ilmiah Volume 13, Nomor 1 A. Jurusan Sosial Ekonomi Fakultas Pertanian Universitas Sam Ratulangi. Manado.

Soerjono Soekanto. 2004. Sosiologi Keluarga, Tentang Ikhwal Keluarga, Remaja dan Anak. Cetakan Ketiga. Jakarta: Rineka Cipta.

Supriatna, N. dan Kosim. 2006. Ilmu Pengetahuan Sosial. Grafindo Media Pratam. Bandung.

Zulfikri., Dolorosa E., dan Komariyati. 2014. Analisis Kontribusi Usaha Ternak sapi Potong Terhadap Pendapatan Rumah Tangga Petani Di Kecamatan Tebas Kabupaten Sambas. Skripsi, Fakultas Pertanian Universitas Tanjungpura. Pontianak. 